\title{
ADAPTASI PERUBAHAN IKLIM KOMUNITAS DESA: STUDI KASUS DI KAWASAN PESISIR UTARA PULAU AMBON
}

\author{
Subair $^{1 \bowtie}$, Lala M. Kolopaking², Soeryo Adiwibowo ${ }^{2}$, M. Bambang Pranowo ${ }^{3}$ \\ ${ }^{1}$ Jurusan Sosiologi Agama Fakultas Dakwah Ushuluddin IAIN Ambon, Indonesia \\ ${ }^{2}$ Departemen Sains Komunikasi dan Pengembangan Masyarakat IPB \\ ${ }^{3}$ Jurusan Sosiologi UIN Syarif Hidayatullah Jakarta
}

Permalink/DOI: http://dx.doi.org/10.15294/komunitas.v6i1.2943

\section{Article History}

Received : Desember 2013 Accepted : Januari 2014 Published : Maret 2014

\section{Keywords}

climate change; vulnerability; adaptation; coping range; community resilience

\begin{abstract}
Abstrak
Tujuan dari penelitian ini adalah menganalisis strategi adaptasi komunitas nelayan terhadap dampak perubahan iklim. Lokasi penelitian di desa nelayan Asilulu, ditetapkan secara purposive mewakili karakteristik desa pesisir di kawasan pantai utara pulau Ambon Maluku. Metodeyang digunakan adalah 'metode kasus historis' sebuah metode studi sosiologi yang memadukan dua pendekatan yaitu sosiologi sejarah dan sejarah sosiologis. Pengumpulan data dilakukan dengan metode hermeunetik dan dialektika dalam waktu kurang lebih 2 tahun (April 2010 - Juni 2012) menggunakan teknik pengamatan berperan serta, focus group discussion, wawancara mendalam, dan studi pustaka. Penelitian menunjukkan hasil bahwa komunitas nelayan di desa Asilulu telah merasakan dampak dari perubahan iklim yang menekan sistem penghidupan mereka meliputi kenaikan permukaan laut, intensitas badai dan gelombang tinggi, perubahan fishing ground dan kekacauan musim tangkap. Kerentanan komunitas dikategorikan tingkat sedang dan karenanya masih dalam area coping range komunitas. Nelayan melakukan adaptasi proaktif dan reaktif dalam strategi adaptasi fisik, sosial-ekonomi, dan sumber daya manusia yang sejauh ini mampu meningkatkan lebar selang toleransi sehingga kerentanan dapat dikurangi dan resiliensi sistem meningkat. Kondisi ini membuat komunitas nelayan cukup resilien.
\end{abstract}

\section{THE ADAPTATION OF VILLAGE COMMUNITY TOWARDS CLIMATE CHANGE: CASE STUDIES IN THE NORTH COAST REGION OF AMBON ISLAND MOLUCCAS}

\begin{abstract}
The purpose of this study is to identify the adaptation strategies of a fishing community to respond the impact of climate change. Location of the study in the fishing village Asilulu, determined purposively to represent the characteristics of the coastal villages in the north coast of the island of Ambon Maluku. The method used is the 'method of historical case' a sociological study method that combines two approaches, historical sociology and sociological history. Data collected between April 2010-June 2012, using the technique of participant observation, focus group discussions, in-depth interviews, and literature. Research shows that the fishing community in the village Asilulu have felt the impact of climate change which suppress their livelihood systems include sea level rise, storm intensity and high waves, changes in fishing grounds and fishing seasons chaos. Community vulnerability and therefore categorized as being still in the area of community coping range. Fishermen proactive adaptation and reactive adaptation strategies in physical, socio-economic, and human resources are so far able to increase the width of the tolerance interval so that vulnerabilities can be reduced and the resilience of the system increases.
\end{abstract}

(C) 2014 Universitas Negeri Semarang 


\section{PENDAHULUAN}

Perubahan iklim adalah fenomena terbaru dan faktor eksternal yang sangat berpengaruh terhadap masyarakat pedesaan saat ini, khususnya di wilayah pesisir dan pulau-pulau kecil. Secara ilmiah, perubahan iklim dan dampaknya telah menimpa banyak wilayah dan berdampak buruk pada sektor pertanian, makanan, air, sosial dan sistem ekologi (IPCC, 2007) Perubahan iklim akan menekan pilihan mata pencaharian yang ada, dan bahkan lebih penting lagi, membuatnya tidak dapat diprediksi karena ketidakstabilan dampak peningkatan iklim (Rosenzweig \& Parry, 1994; Yohe \& Tol, 2002). Tantangan yang akan dihadapi masyarakat pesisir akibat perubahan iklim akan lebih mengkhawatirkan mengingat pengaruhnya yang multi-dimensional melampaui perubahan-perubahan lingkungan dan ekonomi politik yang selama ini telah membuat masyarakat pesisir dalam keadaan rentan (Howden et al. 2007; IPCC, 2007). Secara kolektif, jutaan rumah tangga di wilayah pesisir dapat hancur karena kerusakan infrastruktur, permukiman, dan fasilitas yang diperlukan untuk hidup dan kehidupan serta kemiskinan dan marginalisasi yang dialami komunitas pesisir sepanjang sejarah mereka diperkirakan akan semakin intensif di masa mendatang di bawah perubahan iklim.

Itu berarti lebih dari $60 \%$ penduduk Indonesia yang terkonsentrasi di 10.119 desa pesisir dan di Maluku, penduduk dari 83\% desa yang berada di daerah pantai (DKP Maluku, 2007) akan menghadapi gangguan terhadap sumber mata pencaharian. Masyarakat pesisir yang memiliki ketergantungan yang tinggi terhadap sumber daya pesisir dan perikanan, akan dihadapkan pada tantangan yang tidak seperti yang pernah sebelumnya sebagaimana perubahan iklim yang memberikan pengaruh multi-dimensi (Howden et al., 2007; IPCC, 2007). Dalam situasi tersebut diperkirakan masyarakat pesisir harus berjuang untuk mengatasi tantangan sebesar ini. Kerentanan yang diakibatkan oleh perubahan iklim menjadikan masyarakat pesisir membutuhkan bimbingan dan dukungan untuk mengantisipasi dampak perubahan iklim dan menerapkan strategi adaptasi jika mereka ingin mempertahankan nafkah dan kualitas hidup mereka di masa yang akan datang (Marshall et al., 2010: 1).

Adaptasi merupakan tindakan yang diambil untuk mengurangi kerentanan dan meningkatkan resiliensi (Smit \& Wandel,, 2006). Penekanan pada adaptasi diperlukan karena meskipun skenario dampak perubahan iklim begitu mengkhawatirkan, di beberapa tempat di berbagai belahan dunia dampak perubahan iklim dapat diatasi. Pada kontes lokal (Indonesia) adaptasi diperlukan segera untuk mengurangi dampak perubahan iklim yang sudah berlangsung. Menurut Emil Salim (2010: 11). Apapun yang diperdebatkan di forum Internasional, Indonesia harus sudah melangkah melewati tahap perdebatan itu dan meningkatkan kapasitas anak bangsa menanggapi tantangan perubahan iklim ini. Selain itu, perundingan perubahan iklim skala internasional telah menghasilkan keputusan-keputusan tingkat global yang perlu dianalisis secara ilmiah untuk diaplikasikan pada kondisi nasional suatu negara.

Secara tradisional, analisis sosial atas dampak iklim terhadap sistem sosial ekonomi 'belum' didekati dari perspektif resiliensi, melainkan telah diterapkan dengan cara yang paralel dengan 'pendekatan kerentanan' (Maguire \& Cartwright, 2008). Analisis sosial dengan perspektif kerentanan umumnya berfokus pada aspek-aspek negatif atau kelemahan dari sebuah komunitas. Tradisi pendekatan kerentanan terbatas karena tidak mampu sepenuhnya menangkap, memahami dan mengendalikan semua perubahan dan ancaman yang mungkin dihadapi masyarakat. Karena realitas sosial yang dinamis, terus berubah dan terdiri dari banyak proses yang saling terkait, sangat sulit untuk menangkap perubahan sosial melalui indikasi berbasis indeks kerentanan dan mustahil untuk memprediksi semua kemungkinan hasilnya (Kelly \& Adger, 2000; Walker et al., 2002). Sebaliknya, pendekatan resiliensi seimbang dalam hal yang mencakup kerentanan dalam masyarakat (bukan label seluruh komunitas sebagai 'rentan') serta sumber daya dan kapasitas 
adaptif yang memungkinkan masyarakat untuk mengatasi kerentanan dan mengelola perubahan dengan cara yang positif. Alihalih mencoba untuk memprediksi perubahan spesifik, perspektif resiliensi menerima bahwa perubahan tidak bisa dihindari dan kadang tak terduga (Maguire \& Cartwright, 2008; Resilience Alliance, 2007).

Menggunakan pendekatan resiliensi sosial, penelitian ini merupakan kajian lokalitas dampak perubahan iklim meliputi pemahaman komunitas pedesaan tentang perubahan iklim, kerentanan, adaptasi iklim, serta dimensi-dimensi kemampuan adaptasi yang menjadi modal komunitas menghadapi perubahan iklim. Kajian lokalitas perubahan iklim penting karena dua hal: (1) masih terdapat "gap" data pada tingkat global/ regional untuk dapat diimplementasikan di Indonesia, dan (2) advokasi perubahan iklim membutuhkan formulasi kebijakan berbasis evidensi pedesaan.

\section{METODE PENELITIAN}

Cara umum mengkaji perubahan iklim selama ini adalah melalui pengamatan meteorologis. Dampak iklim seringkali didasarkan pada simulasi model-kenaikan permukaan air laut yang diarahkan sebagai adaptasi biofisik terhadap intrusi air laut ke daratan. Model simulasi seperti itu seringkali non-sensitive terhadap faktor-faktor sosial ekonomi yang sering ditemukan pada kasus studi-studi kualitatif. Dengan cara yang relatif baru, penelitian ini merupakan kajian kerentanan dan resiliensi sekaligus yang menggunakan metode kualitatif, dilaksanakan dengan pendekatan eksplorasi (menggali), bukannya mengenalkan. Informasi yang digali dari masyarakat adalah pandangan masyarakat terhadap kondisi iklim dan perubahannya yang berlaku di lokalitas wilayah penelitian, pandangan yang dapat saja berbeda dengan pandangan ilmuwan.

Metode yang digunakan adalah 'metode kasus historis' sebuah metode studi sosiologi yang memadukan dua pendekatan yaitu sosiologi sejarah (sejarah struktural) dan sejarah sosiologis (sejarah prosesual) serta mengandaikan suatu kajian yang ber- sifat multi-disiplin yang melibatkan disiplin ilmu-ilmu sosiologi, ekologi, antropologi, dan ekonomi. Metode ini merupakan penelitian kualitatif di bawah payung paradigma konstruktivisme, paradigma yang menekankan penelitian harus dilakukan di alam bebas secara sewajarnya untuk menangkap fenomena alam apa adanya dan secara menyeluruh tanpa campur tangan dan manipulasi peneliti (Denzin \& Lincoln, 200o). Pengumpulan data dilakukan dengan metode hermeunetik dan dialektika dalam waktu kurang lebih 2 tahun (April 2010-Juni 2012), menggunakan teknik pengamatan berperan serta, focus group discussion, wawancara mendalam, dan studi pustaka. Informan dipilih secara purposive mewakili informasi sosial-politik-ekonomi-ekologi komunitas dan proses perubahannya dari masa ke masa (1o tahun terakhir) serta keragaman karakteristik komunitas nelayan.

Metode analisis data yang digunakan ialah metode analisis data kualitatif yang terdiri atas dua tahapan. Pertama analisis data kualitatif yang merupakan hasil penelusuran terhadap pernyataan-pernyataan umum tentang hubungan antara berbagai ketegori data untuk membangun pemahaman konseptual tentang realitas berdasarkan temuan data empirik. Meliputi analisis terhadap data yang dihasilkan dari pengamatan langsung secara berpartisipasi, FGD dan wawancara mendalam saat penelitian studi riwayat hidup. Juga analisis terhadap data yang merupakan data sejarah dan teksteks tentang kejadian masa lampau maupun kontemporer berkaitan dengan gejala sosial yang diteliti. Kedua, merupakan pengkategorian data yang dilakukan sesuai dengan rumusan pertanyaan yang diajukan untuk mempermudah interpretasi, seleksi dan penjelasan dalam bentuk deskripsi analisis.

\section{HASIL DAN PEMBAHASAN \\ Pemahaman nelayan lokal}

Komunitas nelayan di lokasi penelitian merasakan terjadi perubahan ekologi dalam o tahun terakhir, meliputi kenaikan permukaan laut, intensitas badai dan gelombang tinggi, perubahan fishing ground dan kekacauan musim tangkap. Sebelum interaksi 
dengan peneliti, nelayan belum pernah terpapar secara intens informasi tentang perubahan iklim. Sebagian mengaku sudah pernah mendengar melalui media massa tetapi tidak tertarik atau tidak dijelaskan secara keilmuan. Pemahaman tentang perubahan lingkungan, oleh karenanya, bukan karena pengetahuan keilmuan perubahan iklim. Pada dasarnya perubahan-perubahan yang terjadi tidak disadari secara langsung mengingat prosesnya berlangsung dalam waktu yang cukup lama dan tidak sporadis. Peneliti menangkap pemahaman itu berdasarkan perubahan-perubahan adaptasi dalam mata pencaharian nelayan dan menganalisis pilihan-pilihan adaptasi yang tersedia. Berikut deskripsi pemahaman nelayan tentang perubahan ekologi yang diasosiasikan dengan perubahan iklim dalam studi-studi ilmiah terkait.

Nelayan secara umum merasakan kenaikan permukaan laut setinggi kurang lebih 3 meter. Di beberapa lokasi, dalam beberapa tahun terakhir nelayan memindahkan tempat penyimpanan perahu ke samping rumah karena tempat penyimpanan perahu yang sebelumnya di belakang rumah karena tempat penyimpanan lama saat ini sudah tergenang air laut. Di lokasi yang lain, halaman rumah penduduk yang dulunya digunakan sebagai tempat menaikkan perahu saat ini telah tergenang air laut. Di lokasi lainnya lagi nelayan membuat 'para-para' sebagai tempat menaikkan perahu agar terhindar dari hempasan ombak selama tidak digunakan. Saat ini, hampir seluruh pantai yang dekat dengan pemukiman penduduk sudah dibangun tembok penahan ombak yang dalam bahasa setempat disebut talit. Nelayan berpendapat bahwa kalau tidak ada talit air laut sekarang ini masuk sampai ke rumah atau ke jalan. Nelayan juga menceritakan bagaimana talit yang dibangun oleh pemerintah banyak yang sudah roboh karena tidak kuat menahan hempasan ombak yang "semakin jahat" menurut mereka. Di sepanjang jalan desa yang berada di bibir pantai juga banyak aspal yang sudah terkelupas dan berlubang dengan genangan air laut di tengah-tengahnya.

Nelayan merasakan bahwa angin ken- cang disertai gelombang pasang beberapa tahun belakangan lebih sering terjadi. Pemerintah sudah membangun talit untuk menahan hempasan ombak tetapi menurut mereka, terkadang hempasan ombak melewati talit yang ada. Di dusun Batu Lubang, posisi talit di depan rumah penduduk yang ke arah pantai sehingga rumah-rumah penduduk terletak antara talit dan laut. Hal ini tentu saja berbahaya. Pada tahun 2011 ada 3 rumah warga yang hilang terseret gelombang pasang.

Di laut tengah laut, cuaca ekstrim juga semakin sering terjadi dan berbeda dengan pengetahuan nelayan yang sudah eksis, relatif susah diprediksi. Nelayan mengaku harus lebih berhati-hati dari masa-masa sebelumnya karena risiko melaut yang semakin tinggi. Tidak jarang nelayan bahkan memilih tidak melaut untuk menghindari risiko bencana. Nelayan menggunakan istilah 'angin tar karuan', 'angin seng ada hidup' atau 'angin ancur sekali' untuk menggambarkan arah mata angin yang tidak bisa diprediksi dan gelombang tinggi dengan ungkapan "ombak su jahat" menggambarkan ombak yang tidak bisa 'dikuasai' lagi. Menghadapi cuaca ekstrim seperti digambarkan itu dengan ungkapan "mati akal" atau "ka laut berarti cari mati”. Nelayan merasakan ombak tidak bisa dikuasai karena arah dan karakteristiknya yang relatif baru bagi pengetahuan dan pengalaman lama mereka. Sesungguhnya nelayan Asilulu selama ini dikenal sebagai pelaut ulung yang "jago" mengatasi gelombang karena sebagai nelayan tuna, mereka berhadapan dengan karakter penangkapan yang jutru masa panen pada musim berombak dan posisinya cukup jauh ke tengah laut. Jenis ombak di tengah laut menurut nelayan saat ini berbeda, tidak lagi sama dengan jenis gelombang yang selama ini mereka kenal. Ungkapan "katong seng tahu angin itu arah dari mana”, menggambarkan bahwa pola angin dan gelombang saat ini benar-benar berbeda. Sementara ungkapan "biar ikan makan bagaimana lai, katong seng barani. Itu perahu bisa terbalik" menggambarkan bahwa perubahan itu melampaui pengetahuan dan keterampilan navigasi mereka. 
Dalam beberapa tahun terakhir nelayan merasakan pengetahuan dan prediksi pola musim sering meleset. Padahal secara turun temurun nelayan meyakini perhitungan yang didasarkan pada pergerakan benda-benda langit (terutama bulan dan bintang) selalu benar dan menjadi pedoman dalam melaut. Selama ini nelayan mengenal dua musim: barat dan timur dengan musim pancaroba pada masa peralihannya, yang dihitung berdasarkan kalender Masehi. Setiap musim dipahami dengan pola angin dan cuaca yang berbeda. Musim barat misalnya identik dengan musim hujan, badai dan ombak. Sebaliknya, musim timur identik dengan keadaan laut yang tenang. Saat ini, nelayan mengeluhkan sering terjadi kekacauan musim yakni gejala musim barat justru terjadi pada musim timur atau sebaliknya. Keadaan cuaca dan badai seperti tidak mengikuti pola itu lagi, melainkan seperti terjadi secara acak. "Katong sekarang seng bisa memperkirakan musim lai", demikian nelayan menyebutnya. Tidak sedikit nelayan yang pergi melaut harus kembali sebelum sempat memancing karena ada badai atau angin kencang yang tidak mereka perkirakan sebelumnya. Nelayan misalnya mepercayai bahwa bulan September adalah musim panen tetapi pada tahun 2010 dan 2011 nelayan belum bisa melaut pada bulan itu karena cuaca ekstrim.

Selain perubahan musim angin, nelayan juga merasakan dan pergeseran musim panen ikan. Selama ini untuk menentukan waktu melaut dan lokasi fishing ground, nelayan berpedoman pada 'kalender musim' yang dibata oleh 'orang tua-tua' yaitu nelayan tua yang dianggap sangat berpengalaman dan memiliki ilmu tentang laut yang luas. Selain berpedoman pada pergerakan benda-benda langit, orang tua-tua biasanya menyusun kalender musim juga berpedoman kepada 'kitab keramat' yang disebut Buku Taju Moloh. Ada sebuah kepercayaan yang diyakini secara turun temurun oleh nelayan adalah bahwa menangkap ikan di laut sangat tergantung pada waktu yang tepat atau disebut tanoar. Tanoar adalah "waktu yang tepat" di mana kawanan ikan tertentu muncul dan nelayan dapat mela- kukan penangkapan. Sekitar 5-7 tahun belakangan, tidak jarang prediksi yang ada pada kalender musim itu tidak relevan lagi dengan kondisi di tengah laut. Saat ini nelayan lebih percaya kepada pedagang pengumpul. Informasi cuaca yang dimiliki pedagang pengumpul biasanya bersumber dari pengamatan keadaan laut yang sebenarnya yang diperoleh secara jaringan. Pengetahuan nelayan setempat bahwa tanoar ikan tuna itu terjadi pada bulan April sampai Mei. Bulan Juni sampai awal September adalah musim paceklik. Sekarang ini tanoar kadang-kadang maju atau mundur sampai 1-2 bulan. Dalam 3 tahun terakhir (2009-2011) bahkan lebih banyak nelayan tidak melaut karena kekacauan musim dan intensitas badai yang terus meningkat.

Hal lain yang mengalami perubahan menurut nelayan adalah posisi fishing ground yang semakin ke tengah laut. Kalau sekitar 7 tahun yang lalu nelayan hanya membutuhkan perjalanan kurang lebih 1 jam untuk menemukan ruaya ikan tuna dan mulai memancing, saat ini mereka harus menghabiskan waktu paling sedikit 3 jam untuk mencapai ruaya ikan. Itu dengan perahu dan mesin yang sama. Nelayan memahami karakter ikan tuna sebagai ikan perenang cepat tetapi sejak dulu pengetahuan yang mereka miliki mampu memprediksi lokasi ikan secara akurat dan memotong ruayanya. Sekarang tidak lagi.

\section{Lokalitas Dampak Perubahan Iklim}

Identifikasi dampak perubahan iklim dilakukan pada tiga aspek yaitu dampak pada aspek fisik, aspek ekologi dan aspek sosial ekonomi. Dampak fisik dan ekologi diamati langsung pada aspek-aspek fisik yang berubah di lokasi penelitian dan menanyakannya kepada nelayan. Kerusakan jalan dan tembok penahan ombak sepanjang jalan merupakan pemandangan sepanjang menyusur jalan pesisir pantai dari kota Ambon ke desa Asilulu. Air laut menggenang di banyak badan jalan, sedang tembok penahan ombak (talit) banyak yang sudah terendam air laut. Dampak kenaikan permukaan air laut belum dirasakan oleh nelayan sebagai ancaman atau masalah sejauh ini. 
Kerusakan jalan dan tembok penahan gelombang dirasakan hanya mengganggu kenyamanan mobilisasi penduduk ke Ambon atau ke daerah lainnya tapi belum sampai memutus akses transportasi. Dampak yang dirasakan sebagai bencana adalah seringnya terjadi angin kencang disertai gelombang pasang yang 'dahsyat' dalam setidaknya 5 tahun terakhir. Pada tahun 2010, terjadi badai yang disertai terjangan ombak yang membuat sedikitnya 3 rumah hancur dan terseret ke tengah lautan. Dampak ekologis lainnya, tanaman pesisir seperti pohon-pohon besar sudah hampir tidak ada lagi karena terbawa air laut.

Dampak sosial-ekonomi yang ditimbulkan dari perubahan iklim yang diidentifikasi dari pemahaman nelayan. Perubahan iklim menyebabkan menurunnya hasil tangkapan nelayan yang dipicu oleh sulitnya menentukan musim dan wilayah tangkapan ikan, akibatnya biaya melaut membengkak terutama untuk biaya mengejar musim. Nelayan melaporkan bahwa perubahan cuaca yang tidak bisa diprediksi ketika mereka sedang berada di laut sering memaksa mereka untuk kembali ke daratan bahkan sebelum memperoleh apa-apa. Pada musim ikan mati, apabila cuaca di lautan bisa dikuasai, dahulu nelayan setiap hari (kecuali pada hari Jumat) bisa melaut setiap hari sepanjang musim itu (berlangsung sekitar 3 bulan). Dalam sepuluh tahun terakhir, ratarata nelayan hanya bisa melaut sampai 15 trip perbulan. Bahkan pada 'musim panen' tahun 2011, nelayan sama sekali tidak melaut karena keadaan lautan yang tidak memungkinkan.

Dampak gelombang ekstrim serta badai membuat nelayan lebih memilih tidak melaut pada musim-musim untuk mencegah kemungkinan buruk yang dapat terjadi. Dalam 10 tahun terakhir periode musim gelombang ekstrim serta badai semakin sering berakibat pada semakin seringnya nelayan tidak melaut yang berarti tidak adanya pemasukan untuk kebutuhan hidup rumah tangga sehari-hari. Jarangnya frekuensi melaut dan semakin membengkaknya biaya operasional berimplikasi kepada semakin tergantungnya nelayan kepada pedagang pengumpul. Dari aspek struktur sosial, pengumpul berubah menjadi pengusaha lokal yang berstatus tinggi dalam masyarakat sedang nelayan semakin terpuruk sebagai klien dengan tingkat ketergantungan yang tinggi.

Perubahan lingkungan diasosiasikan dengan perubahan yang iklim tidak hanya melulu berdampak negatif kepada komunitas nelayan, melainkan juga berdampak positif pada beberapa aspek. Tekanan lingkungan yang dirasakan semakin berat dalam mata pencaharian secara tidak langsung memupuk rasa kebersamaan anggota komunitas karena menyadari bahwa situasi saat ini semakin tidak bisa diatasi sendiri, baik oleh satu unit rumah tangga atau individu. Beberapa kali menghadapi kondisi krisis, terutama krisis ekonomi yang dipicu oleh frekuensi melaut yang tidak menentu, membuat nelayan menyadari bahwa dukungan sosial sangat penting sebagai alternatif yang akan membantu mereka melewati krisis. Sumber dukungan sosial adalah jaringan sosial, sementara jaringan sosial hanya bisa dibangun dan dijaga dengan asas saling percaya (trust). Sebagai akibatnya, nelayan lebih menjaga hubungan dengan sesama komunitas serta dengan pihak luar yang berhubungan dengan mereka.

Perubahan kondisi laut dan perilaku ikan memicu nelayan untuk membuka diri terhadap pengetahuan baru dan mengadopsi teknologi-teknologi baru yang bisa memperkaya pengetahuan dan keterampilan mereka menghadapi tantangan yang semakin beragam. Tantangan melaut yang semakin berat dengan risiko bencana yang semakin tinggi secara tidak langsung membuat komunitas nelayan lebih dekat kepada Tuhan. Nelayan meyakini bahwa rezeki itu ketentuan Allah sehingga ada atau tidak adanya, sedikit atau banyaknya, dipahami sebagai bagian dari kasih sayang Allah kepada mereka, sebagian dipahami sebagai ujian untuk mereka berusaha dan bekerja lebih giat lagi. Hari Jumat adalah hari libur nelayan melaut, bahkan pada musim panen sekalipun. Meskipun banyak nelayan yang tidak ke masjid melaksanakan shalat Jumat pada hari itu, mereka tetap tidak pergi ke laut 


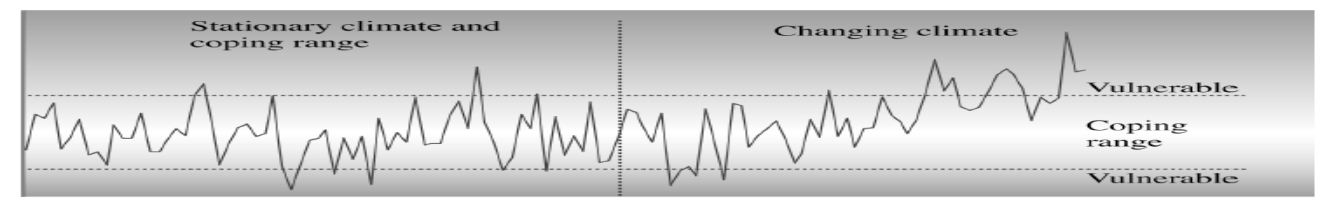

Gambar 2. Konsep hubungan antara selang toleransi, kerentanan, dan perubahan iklim (Sumber: Jones et al. 2004).

untuk menghormati hari Jumat. Beriman kepada Allah menurut nelayan merupakan kunci untuk tetap bertahan dalam menghadapi tantangan mata pencaharian yang dirasa semakin berat.

\section{Aspek Kerentanan Nelayan}

Analisis kerentanan pada penelitian ini mengkaji tiga komponen: paparan (exposure), kepekaan (sensitivity), dan kemampuan adaptasi (adaptive capacity). Menggunakan konsepsi 'selang toleransi' (coping range) dari Jones et al. (2004), kerentanan dipahami sebagai keadaan di mana perubahan iklim melewati batas kritis (critical threshold), yang berarti kondisi iklim saat itu melewati batas kemampuan mereka untuk mengatasinya (Gambar 2).

\section{Tingkat Paparan}

Paparan adalah sejauh mana perubahan iklim bersinggungan dengan pola kehidupan dan penghidupan masyarakat maupun ekosistem (IPCC, 2007). Faktor penentu paparan adalah kecenderungan iklim saat ini (musim), kejadian yang diakibatkan iklim, perkiraan iklim, serta data masyarakat dan ilmuwan.

Masyarakat pada desa Asilulu ini telah mengalami beberapa hal terkait perubahan iklim sebagai berikut:

Masa berlangsungnya angin musim dan musim penghujan berubah: bergeser hingga lebih dari satu bulan, tanda-tanda datangnya musim seluruhnya tidak sama lagi, kemampuan masyarakat untuk menduga musim tidak lagi dapat diandalkan.

Kejadian cuaca buruk yang merusak harta benda dan mengancam keselamatan jiwa berlangsung hampir setiap tahun.

Luasan wilayah yang tergenang air laut karena pasang tertinggi atau kenaikan permukaan laut menunjukkan pertambahan setiap tahunnya dalam 10 tahun terakhir.
Dengan demikian disimpulkan bahwa tingkat paparan dikategorikan tinggi. Argumentasi ini dikuatkan oleh kenyataan bahwa sebagian besar atau hampir seluruh sumber daya alam dipengaruhi oleh perubahan kondisi iklim dan atau hampir seluruh penduduk desa yang sumber penghidupannya bergantung pada kondisi iklim. Desa Asilulu terletak pada kawasan pesisir utara Pulau Ambon di mana lebih dari 90 persen penduduknya bekerja sebagai nelayan atau bergantung kepada sumber daya pesisir dan laut (Data Monografi Desa Asilulu 2010). Ini berarti bahwa hampir seluruh sumber penghidupan/mata pencaharian masyarakat bergantung pada kondisi iklim.

\section{Tingkat Kepekaan}

Kepekaan adalah dampak dari perubahan iklim, meliputi dampak dari perubahan pola musim jangka panjang, kejadian cuaca buruk jangka pendek/singkat, dan bencana terkait perubahan iklim (IPCC, 2007). Hasil analisis kepekaan komunitas di lokasi penelitian disajikan pada tabel 1.

Hasil penilaian kepekaan komunitas nelayan di lokasi penelitian sebagaimana diuraikan pada tabel 1 disimpulkan tinggi. Secara umum, penyebab dari tingginya keterpaparan ini adalah karakter masyarakat yang bergantung hanya pada satu sumber daya saja yakni sumber daya laut.

\section{Potensi dampak}

Potensi dampak adalah dampak terpendam yang merupakan gabungan dari paparan dan kepekaan. 'Potensi dampak' menggambarkan gabungan luasan, intensitas dan frekuensi dampak perubahan kondisi iklim pada suatu wilayah. Penilaian potensi dampak melihat tingkatan paparan dan kepekaan menggunakan matrik 1.

Hasil analisis disimpulkan bahwa tingkat potensi dampak pada level tinggi. 
Tabel 1. Tingkat kepekaan komunitas nelayan di Asilulu

\begin{tabular}{lll}
\hline No. & Pengaruh perubahan kondisi iklim dan cuaca buruk & $\begin{array}{l}\text { Rentang tingkat } \\
\text { kepekaan }\end{array}$ \\
\hline 1 & $\begin{array}{l}\text { Perubahan kondisi iklim dirasakan pengaruhnya pada } \\
\text { kegiatan penghidupan (mata pencaharian) masyarakat }\end{array}$ & Besar \\
2 & $\begin{array}{l}\text { Dalam satu musim kegiatan penghidupan masyarakat } \\
\text { terhambat }\end{array}$ & $\begin{array}{l}\text { Satu musim atau } \\
\text { lebih }\end{array}$ \\
3 & $\begin{array}{l}\text { Pengaruh perubahan kondisi iklim pada kesehatan dan } \\
\text { ketenangan jiwa masyarakat } \\
\text { Pengaruh perubahan kondisi iklim pada sumber daya } \\
\text { alam perikanan }\end{array}$ & Cukup besar \\
5 & $\begin{array}{l}\text { Kejadian cuaca buruk yang mengakibatkan kerusakan } \\
\text { harta benda dan kecelakaan dalam sepuluh tahun terakhir }\end{array}$ & Beberapa kali \\
\hline Pengaruh Perubahan Kondisi Iklim Secara Keseluruhan & Tinggi \\
\hline
\end{tabular}

Matrik 1. Penilaian Potensi Dampak

\begin{tabular}{|c|c|c|c|c|}
\hline \multirow{5}{*}{ 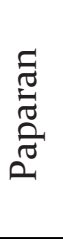 } & \multicolumn{4}{|c|}{ Kepekaan } \\
\hline & & Hampir tidak ada & Sedang & Parah \\
\hline & Kecil hingga tidak ada & Kecil & Kecil & Sedang \\
\hline & Beberapa & Kecil & Sedang & Tinggi \\
\hline & Hampir semuanya & Sedang & Tinggi & Tinggi \\
\hline
\end{tabular}

Kondisi ini menggambarkan keseluruhan kerugian yang mungkin terjadi bila kondisi iklim berubah. Tingginya potensi dampak berdasarkan argumentasi bahwa tingkat paparan meliputi hampir semua komunitas nelayan dan kepekaan nelayan serta sumber daya alam terhadap dampak perubahan iklim kategori tinggi.

\section{Kemampuan Adaptasi}

Kemampuan adaptasi menunjukkan kemampuan dari suatu sistem untuk melakukan penyesuaian (adjust) terhadap perubahan iklim sehingga potensi dampak negatif dapat dikurangi dan dampak positif dapat dimaksimalkan atau dengan kata lain kemampuan untuk mengatasi konsekuensi dari perubahan iklim (to cope with the consequences) (Jones et al., 2004). Penilaian kemampuan adalah mengkaji keberadaan sumber daya yang dimiliki oleh masyarakat yang menunjukkan kemampuan adaptasi yang meliputi kondisi pada aspek sosialekonomi, penghidupan dan kelembagaan yang memungkinkan masyarakat untuk menghadapi dan mengatasi ancaman perubahan iklim. Hasil analisis kemampuan adaptasi komunitas di lokasi penelitian disajikan pada tabel 2.

Hasil penilaian kemampuan adaptasi komunitas desa nelayan di lokasi penelitian disimpulkan tinggi atau baik dengan berbagai argumentasi sebagaimana diuraikan pada tabel 2 di atas.

Setelah mengetahui tingkat paparan, kepekaan dan kemampuan adaptasi sebagai komponen yang menyusun tingkat kerentanan, maka selanjutnya dapat dibuat penilaian terhadap tingkat kerentanan komunitas nelayan di lokasi penelitian. Sistematika penilaiannya berpedoman matrik penilaian kerentanan masyarakat (matrik 2).

Potensi dampak perubahan iklim yang tinggi tetapi diimbangi kemampuan adaptasi yang juga tinggi menyebabkan tingkat kerentanan sistem komunitas nelayan dikategorikan sedang. Dengan kata lain, dampak perubahan iklim masih dalam selang toleransi (coping range) sistem komunitas desa yang berarti komunitas masih mam- 
Tabel 2. Tingkat kemampuan serta acuan kondisi umum komunitas nelayan di Asilulu

\begin{tabular}{|c|c|c|}
\hline No & Ciri Acuan & Tingkatan \\
\hline 1 & $\begin{array}{l}\text { Masyarakat memiliki kebersamaan, kebiasaan gotong royong, me- } \\
\text { miliki pemimpin dan sekelompok orang yang bekerja untuk kepen- } \\
\text { tingan desa, kebiasaan bermusyawarah membuat rencana bersama, } \\
\text { dan nilai-nilai baik dalam mengelola lingkungan }\end{array}$ & Tinggi/Baik \\
\hline 2 & $\begin{array}{l}\text { Masyarakat memiliki keahlian, kemampuan, dan kerjasama serta } \\
\text { motivasi kuat untuk mengatasi masalah perubahan kondisi iklim } \\
\text { terhadap sumber penghidupan, di antaranya dengan mata penca- } \\
\text { rian tambahan atau pilihan lain, dan mengatasi masalah cuaca bu- } \\
\text { ruk yang mengakibatkan kerusakan harta benda dan keselamatan } \\
\text { jiwa. }\end{array}$ & Tinggi/Baik \\
\hline 3 & $\begin{array}{l}\text { Masyarakat memiliki kemampuan membangun hubungan dan ker- } \\
\text { jasama yang baik dengan pihak luar (LSM, swasta, pemerintah dae- } \\
\text { rah) }\end{array}$ & $\begin{array}{l}\text { Sedang/ } \\
\text { Cukup }\end{array}$ \\
\hline 4 & $\begin{array}{l}\text { Lingkungan tempat bermukim yang sehat, sumber daya alam yang } \\
\text { beragam, dan sumber air yang sehat dan cukup }\end{array}$ & Tinggi/Baik \\
\hline 5 & $\begin{array}{l}\text { Memiliki pengetahuan dan pengalaman menghadapi perubahan } \\
\text { lingkungan sebelumnya. }\end{array}$ & Tinggi/Baik \\
\hline 6 & $\begin{array}{l}\text { Masyarakat memiliki jaringan sosial yang kuat yang menjadi sumber } \\
\text { dukungan sosial }\end{array}$ & Tinggi/Baik \\
\hline \multicolumn{2}{|r|}{ Nilai tingkatan kemampuan adaptasi masyarakat (rata-rata) } & Tinggi/Baik \\
\hline
\end{tabular}

Matrik 2. Penilaian kerentanan masyarakat

\begin{tabular}{llccc}
\hline & \multicolumn{4}{c}{ Kemampuan Adaptasi } \\
\cline { 2 - 5 } Potensi & Tinggi Sekali & Tinggi & Sedang & Tinggi \\
\cline { 2 - 5 } Dampak & Tinggi & Tinggi & Tinggi & Sedang \\
& Sedang & Sedang & Sedang & Sedang \\
& Rendah & Rendah & Rendah & Rendah \\
\hline
\end{tabular}

pu mengatasinya dan sebagai dampaknya nelayan belum mengalami kerugian yang berarti.

\section{Strategi Adaptasi: Mereduksi Kerentan- an, Meningkatkan Resiliensi}

Adaptasi merupakan tindakan nyata penyesuaian sistem lingkungan fisik dan sosial dengan beberapa prinsip pendekatan untuk menghadapi kemungkinan timbulnya dampak negatif dari perubahan iklim. Tingkat kemampuan sistem untuk menghadapi konsekuensi dari perubahan iklim dapat digambarkan sebagai selang toleransi terhadap besar, intensitas dan laju dari perubahan iklim. Mengacu pada konsep selang toleransi (Gambar 3), adaptasi diperlukan untuk memperlebar selang toleransi (coping range) mengatasi kerentanan yang semakin tinggi dipicu dampak negatif perubahan iklim (Gambar 4). Kondisi pada saat selang toleransi lebih lebar dari kerentanan sistem iklim disebut dapat resilien terhadap perubahan iklim.

Resiliensi dalam studi ini dipahami sebagai kemampuan masyarakat untuk mengatasi gangguan atau perubahan dan mempertahankan perilaku adaptif. Dalam konteks perubahan iklim, resiliensi adalah kemampuan menanggapi dampak peruba- 

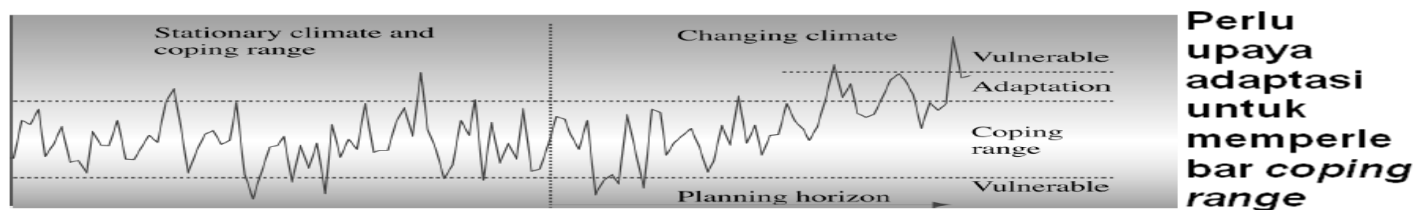

Gambar 4. Konsep hubungan antara selang toleransi, kerentanan, perubahan iklim, dan adaptasi (Sumber: Jones et al. 2004).

han iklim sambil terus berfungsi secara teratur. Definisi ini merupakan 'sintesis' dari konsep resiliensi Folke (2006), Manyena (2006), Resilience Alliance (2009), Carpenter et al. (2001), dan Nelson et al. (2007).

Mengantisipasi kenaikan air laut, terdapat beberapa strategi adaptasi yang dilakukan. Pertama, membangun talit yang secara langsung dapat menahan kenaikan permukaan laut, hantaman gelombang pasang dan rob. Talit yang ada saat ini seluruhnya dibangun oleh pemerintah melalui beberapa proyek. Kedua, nelayan membuat para-para yaitu tempat penyimpanan perahu selama tidak melaut di atas air laut mengantisipasi hempasan gelombang pasang yang berpotensi mengantam perahu. Para-para dibuat antara talit dan bibir pantai, dari batang kayu-kayu kecil yang tahan terhadap air laut. Nelayan tidak menanam pohon bakau sebagaimana adaptasi yang umum dilakukan untuk mencegah dampak kenaikan air laut dan gelombang pasang karena menurut mereka pantai di Asilulu berbatu sehingga pohon-pohon tidak bisa tumbuh dengan baik.

Dampak perubahan iklim yang diterima oleh masyarakat nelayan yang memancing beberapa adaptasi yang bersifat reaktif, antara lain (1) melakukan strategi adaptasi mengejar musim. Strategi ini merupakan bentuk adaptasi yang dilakukan oleh nelayan apabila di wilayah perairan sekitar mengalami masa paceklik. Sejak zaman dahulu, nelayan mempercayai bahwa nenek moyang mereka sudah melakukan strategi mengejar musim meskipun hanya menggunakan perahu semang tradisional. Yang berbeda dengan saat ini adalah kalau dulu pengetahuan dan perhitungan musim yang diaplikasikan dengan bentuk kalender musim menjadi pedoman yang akurat, saat ini sudah lebih sering tidak akurat. Perkiraan nelayan tentang musim dan tempat panen ikan tuna semakin sering salah daripada benar. Saat ini nelayan lebih percaya kepada pedagang pengumpul. Informasi cuaca yang dimiliki pedagang pengumpul biasanya bersumber dari pengamatan keadaan laut yang sebenarnya yang diperoleh secara jaringan. Setiap pengumpul biasanya memiliki nelayan di setiap daerah di Maluku dan perkembangan teknologi telepon genggam yang sudah sampai di pelosok menfasilitasi penyebaran informasi itu; (2) nelayan membentuk kelompok operasi penangkapan. Menyadari risiko melaut yang semakin besar dan mengantisipasi semakin seringnya prediksi cuaca dan fishing ground meleset, nelayan melakukan operasi penangkapan secara berkelompok yang terdiri dari 4-5 perahu. Keuntungan dari melaut secara berkelompok ini adalah dengan banyaknya nelayan yang terlibat, berbagai macam pengetahuan dan pengalaman dikombinasikan untuk menentukan jenis umpan yang sedang disukai ikan tuna, lokasi ikan tuna, dan memprediksi ancaman badai selama di tengah lautan. Kelompok penangkapan juga dimaksudkan sebagai tindakan mengantisipasi badai yang sering tidak terduga untuk saling menolong di tengah laut; (3) pada kondisi seluruh fishing ground yang mereka ketahui tidak bisa diakses baik karena paceklik atau karena cuaca yang tidak bisa diprediksi, nelayan lebih memilih untuk tidak melakukan kegiatan penangkapan dan beralih mengerjakan kegiatan off fishing. Pilihan adaptasi seperti dimungkinkan dengan kepemilikan setiap keluarga atas lahan perkebunan yang disebut dengan dusung. Di Petuanan Batu Lubang, tidak menentunya hasil tangkapan dan meningkatnya biaya operasional disikapi dengan 
tindakan adaptasi beralih menangkap ikan dasar (sebutan untuk ikan di perairan dangkal) untuk kebutuhan sehari-hari. Nelayan di wilayah ini umumnya memiliki dua jenis perahu penangkap ikan yaitu perahu fiber dilengkapi mesin untuk penangkapan jauh (khusus ikan tuna) dan perahu semang atau kole-kole tanpa mesin untuk penangkapan ikan di perairan dangkal. Pilihan ini diambil mengingat masyarakat di Petuanan ini adalah masyarakat pendatang dari etnis $\mathrm{Bu}-$ ton yang tidak memiliki lahan sebagaimana penduduk asli Asilulu.

Menghadapi pergeseran fishing ground yang semakin jauh ke tengah laut, sejak tahun 1990an nelayan mengganti perahu tradisional yang selama ini mereka gunakan dan buat sendiri dengan perahu berbahan fiber yang dibeli di luar desa. Perahu fiber (nelayan menyebutnya bodi) bobotnya ringan dan bentuknya dimodifikasi untuk bergerak cepat memotong pergerakan ruaya ikan tuna. Sedangkan untuk menyesuaikan kondisi laut yang berombak lebih tinggi dari sebelumnya serta disertai angin kencang, nelayan mengembangkan teknik pemancingan menggunakan layang-layang yang cocok untuk memancing pada kondisi lautan yang berombak disertai angin kencang. Layang-layang dibuat sendiri oleh nelayan, biasanya dari bambu atau rotan dan plastik yang anti air. Prinsip penggunaan layang-layang adalah membuat umpan seperti ikan umpan hidup yang bermain di air. Jadi ikan tuna mengejar umpan itu seperti mengejar ikan hidup. Dibutuhkan keahlian khusus menerbangkan layang-layang untuk mengatur umpan menyerupai ikan hidup. Penggunaan layang-layang menurut nelayan sangat efektif saat ini apalagi memancing dengan cara lama tidak mungkin dilakukan pada situasi seperti saat ini.

Dampak perubahan iklim beresiko membawa dampak krisis terhadap sistem pencaharian nelayan. Pergantian alat tangkap tradisional yang sebelumnya bisa mereka produksi sendiri, biaya melaut yang semakin tinggi sebagai konsekuensi dari modernisasi sarana tangkap dan strategi mengejar musim serta frekuensi melaut yang terganggu oleh cuaca yang tidak bisa diprediksi dan intensitas cuaca ekstrim yang meningkat dari tahun ke tahun membutuhkan biaya yang sangat besar bagi nelayan. Untuk itu nelayan memperkuat jaringan sosial sebagai sumber dukungan sosialnya. Dukungan sosial terutama diperoleh dari lembaga pengumpul. Sampai di sini, dampak perubahan iklim masih bisa ditolerir oleh nelayan berkat sokongan modal dan dukungan moda produksi pada penerapan strategi mengejar musim.

Terakhir, nelayan menyerahkan segala ketidakmampuan mereka menghadapi perubahan-perubahan yang mengancam mata pencaharian dan bahkan nyawa mereka kepada kekuasaan Allah. Menurut mereka, Allah itu Maha Adil sehingga usaha yang mereka lakukan untuk menghidupi keluarga pasti akan dibalas oleh Allah dalam bentuk kemudahan dan rezeki. Dalam konteks ini, kelembagaan keagamaan berperan besar sebagai pembina rohani masyarakat, juga memiliki peranan yang cukup penting dalam memotivasi masyarakat dalam peningkatan kesejahteraan nelayan.

Dari seluruh strategi adaptasi yang dilakukan sebagaimana diuraikan di atas, dapat dikatakan bahwa komunitas nelayan di desa Asilulu mampu mengatasi dampak perubahan iklim, terutama melalui modifikasi jaringan dan kelembagaan sosial yang ada di tingkat desa. Nelayan menjadikan jaringan dan kelembagaan tersebut, khususnya kelembagaan 'pengumpul' sebagai sumber dukungan sosial yang berperan sebagai 'cadangan sosial' pada saat terjadi krisis yang diakibatkan oleh dampak negatif dari perubahan iklim. Dengan kata lain, pada batas ini, adaptasi yang dilakukan mampu meningkatkan lebar 'selang toleransi' sehingga kerentanan dapat dikurangi dan resiliensi sistem meningkat. Kondisi ini membuat komunitas nelayan di lokasi ini resilien terhadap perubahan iklim. Sejauh ini masyarakat mampu mengatasi gangguan atau perubahan dan mempertahankan perilaku adaptifnya.

\section{Jaringan Sosial dan Dukungan Sosial}

Pengumpul adalah kelembagaan yang muncul relatif baru yakni ketika nelayan 
mengganti orientasi pasar produksinya. Keberadaan pedagang pengumpul dan institusi patron-klien yang terbentuk karenanya itu menentukan dampak perubahan iklim terhadap masyarakat nelayan di Asilulu. Pada saat modal melaut tidak lagi mencukupi karena perolehan hasil dari melaut tidak cukup untuk membiayai trip berikutnya, pedagang pengumpul menjadi penyelamat yang mempertahankan nelayan tetap melaut. Pada fase ini, dampak perubahan iklim masih bisa ditolerir oleh nelayan berkat sokongan modal dan dukungan "pasar bergerak" yang mengikuti lokasi penangkapan nelayan. Ini berarti bahwa nelayan memanfaatkan jaringan sosial yang ada sebagai sumber dukungan sosial. Jaringan sosial yang lebih dekat lebih mudah untuk melakukan penyatuan sumber daya komunal. Pedagang pengumpul yang seluruhnya adalah penduduk pribumi (orang negeri) terikat lebih kuat dengan nelayan dari golongan masyarakat pribumi juga. Pada keadaan ini, kelembagaan pedagang pengumpul tidak hanya berfungsi sebagai pasar bagi nelayan tetapi juga sebagai "cadangan sosial" yang digunakan terjadi krisis sosial ekonomi sebagai akibat dari dampak perubahan iklim.

Selain kelembagaan lokal yang telah ada dalam usaha perikanan tuna di Asilulu, kelembagaan sosial lainnya yang turut berperan adalah lembaga keagamaan, pihak pemerintah desa/negeri dan lembaga kepemudaan. Kelembagaan keagamaan selain melakukan tugas dan fungsi pokok sebagai pembina rohani masyarakat, juga memiliki peranan yang cukup penting dalam memotivasi masyarakat dalam peningkatan kesejahteraan mereka. Sementara pemerintah desa/negeri melaksanakan fungsi dan wewenangnya sebagai fasilitator, dinamisator dalam menggerakan potensi sumber daya di desa/negerinya. Begitu pula dengan lembaga kepemudaan berperan dalam menggerakkan masyarakat desa dalam pelaksanaan dan pemanfaatan sumber daya yang dimiliki oleh desa tersebut. Platform pengelolaan sumber daya di Asilulu dalam istilah setempat dinamakan "tiga tungku" yang terdiri atas lembaga pemerintah, (raja adalah pemangku adat di desa/negeri), lem- baga pendidikan dalam hal ini adalah guru dan lembaga agama yakni masjid. Keterkaitan antara ketiga lembaga yang merupakan paltform pengelolaan sumber daya yang terdapat di negeri Asilulu memberikan makna bahwa peran serta menjadi dasar bagi pengembangan masyarakat di negeri Asilulu.

\section{SIMPULAN}

Komunitas nelayan di desa Asilulu telah merasakan dampak dari perubahan iklim yang menekan sistem penghidupan mereka. Pemahaman nelayan tentang perubahan iklim didasarkan pada pengalaman belaka dan bukan pada keilmuan perubahan iklim itu sendiri. Hal itu dan tingkat paparan serta kepekaan yang tinggi menempatkan nelayan pada posisi yang sangat beresiko terhadap dampak negatif dari perubahan iklim. Kemampuan adaptasi yang tinggi mengurangi tingkat resiko tersebut sehingga kesimpulannya: kerentanan komunitas desa nelayan Asilulu dikategorikan sedang. Mengoptimalkan kemampuan adaptasi yang dimiliki melalui praktek strategi adaptasi dilakukan dengan memodifikasi pilihanpilihan pengetahuan, pengalaman, kearifan lokal, keterampilan dan jaringan sosial yang tersedia mampu mereduksi kerentanan dan meningkatkan resiliensi komunitas terhadap dampak negatif perubahan iklim. Sejak rentang 10 tahun terakhir, pembaruan dan modifikasi pengetahuan lokal penghidupan serta dukungan eksternal kelembagaan yang menfasilitasi pelaksanaannya terbukti masih mampu menjamin komunitas nelayan dalam keadaan yang resilien.

Dibutuhkan keterlibatan banyak pihak, terutama peran aktif pemerintah pada semua skala mendukung masyarakat dalam usahanya beradaptasi terhadap dampak perubahan iklim. Pada strategi mengejar musim misalnya, pola adaptasi ini sebenarnya akan lebih optimal jika disertai adaptasi yang lebih sistematis berupa penerapan teknologi dalam memprediksi lokasi ikan. Pengetahuan dan perkiraan musim dan cuaca oleh nelayan yang mulai sering tidak relevan dalam strategi mengejar musim karena nelayan lebih menggunakan feeling daripada pengetahuan ilmiah. Oleh kare- 
nanya pemerintah perlu menguatkan "sekolah iklim lapang" yang melayani kebutuhan informasi iklim yang akurat dan lebih dari itu, meminimalisir resiko kegagalan melaut serta resiko bencana di tengah laut. Upaya pemerintah untuk berkonsultasi dengan masyarakat menjadi jalan terbaik sebelum masyarakat bertindak dengan pengetahuan mereka sendiri. Selain itu, pembangunan fasilitas-fasilitas pendukung usaha perikanan mutlak diperlukan karena nelayan yang sejahtera relatif mampu beradaptasi lebih luwes dengan banyak pilihan adaptasi yang mampu dilakukannya daripada nelayan dengan cap tradisional dengan banyak keterbatasan. Tidak ketinggalan, Lembaga Swadaya Masyarakat didorong untuk terus melakukan identifikasi dan meningkatkan kesadaran masyarakat terhadap dampak dari perubahan iklim tersebut.

\section{DAFTAR PUSTAKA}

Carpenter, S., Walker, B., Anderies, J. M., \& Abel, N. 2001. From Metaphor to Measurement: Resilience of What to What? Ecosystems 4(8): 765781.

Denzin, N.K. \& Y.S. Lincoln (eds.). 200o. Handbook of Qualitative Research (Second Edition), Thousand Oaks: Sage Pul. Inc.

Dinas Perikanan dan Kelautan (DKP) Provinsi Maluku, 2007. Laporan Tahunan 2006. Ambon.

Folke, C. 2006. Resilience: the emergence of a perspective for social-ecological systems analyses. Global Environmental Change 16: 253-67.

Howden, S. M., J. F. Soussana, F. N. Tubiello, et al. 2007. Adapting agriculture to climate change. Proceedings of the National Academy of Sciences 104(50): 19691-96.

Intergovernmental Panel on Climate Change (IPCC) 2007: Climate Change 2007: Impacts, Adaptation and Vulnerability. Contribution of Working Group II to the Fourth Assessment Report of the Intergovernmental Panel on Climate Change. M.L. Parry, O.F. Canziani, J.P. Palutikof, P.J. van der Linden and C.E. Hanson, Eds. Cambridge: Cambridge University Press.

Jones, R., Boer, R., Mearns, L., and Magezi, S. 2004. Assessing current climate risks. In Bo Lim, Erika Spanger-Siegfried, Ian Burton, Eizabeth Malone and Saleemul Huq (eds). Adaptation Policy Frameworks for Climate Change: Devel- oping Strategies, Policies and Measures. Cambridge University Press. pp: 91-117. Available on line at http://www.undp.org/gef/o5/kmanagement/pub_practitioner.html

Kelly, P. M. and W. N. Adger. 20oo. Theory and practice in assessing vulnerability to climate change and facilitating adaptation. Global Environmental Change 47(4):325-52.

Maguire, Brigit and S. Cartwright. 2008. Assessing a community's capacity to manage change: A resilience approach to social assessment. Australia: Bureau of Rural Sciences.

Manyena, S.B. 2006 'The Concept of Resilience Revisited', Disasters 30(4): 433-50

Marshall N.A., Marshall P.A., Tamelander J., Obura D., Malleret-King D. and Cinner J.E. 2010. A Framework for Social Adaptation to Climate Change; Sustaining Tropical Coastal Communities and Industries. Gland, Switzerland, IUCN

Mayunga, J.S. (2007) 'Understanding and Applying the Concept of Community Disaster Resilience: A Capital-Based Approach', draft working paper prepared for the summer academy, Megacities as Hotspots of Risk: Social Vulnerability and Resilience Building, Munich, Germany, 22-28 July 2007

Nelson, D.R, Adger WN, Brown K. 2007. Adaptation to Environmental Change: Contributions of a Resilience Framework. Annual Review of Environment and Resources 32: 395-419.

Resilience Alliance. 2007. Assessing and managing resilience in social-ecological systems: A practitioners workbook (Version 1.0). www.resalliance.org:

Resilience Alliance. 2009. Resilience, 25 December, www. resalliance.org/576.php

Rosenzweig, C., and M. Parry. 1994. Potential impact of climate change on world food supply. $\mathrm{Na}$ ture 367: 133-38.

Salim, E. 2010. Ratusan Bangsa Merusak Satu Bumi. Jakarta: Penerbit Buku Kompas.

Smit, B. and Wandel J. 2006. Adaptation, adaptive capacity and vulnerability. Global Environmental Change, 16: 282-92.

Walker, B., S. Carpenter, J. Anderies, N. Abel, G. Cumming, M. Janssen, L. Lebel, J. Norberg, G. Peterson and R. Pritchard. 2002. Resilience management in socio-ecological systems: A working hypothesis for a participatory approach, Conservation Ecology, 6(1), pp. 14 at http:// www.consecol.org/voli6/iss1/art14.

Yohe, G. and R.S.J. Tol. 2002. Indicators for social and economic coping capacity-moving toward a working definition of adaptive capacity, Global Environmental Change 12: 25-40. 